\title{
Force and Settlement Characteristics of an Embankment on Soft Consolidating Soil with Lime Columns
}

\author{
M Prasanna Kumar
}

\begin{abstract}
Embankment supported on soft soil with lime column is analyzed. The lime column is modeled using a two noded plane frame element with three degrees of freedom (DOF) (two transnational and one rotational), whereas the soil stress- strain behavior is presumed to be non-lining and modeled by a Cam-Clay model. The properties of lime column is obtained from a stressstrain curve obtained from a laboratory test. It is concluded from the study that addition of lime column in soft soil reduces the settlement after the construction.
\end{abstract}

Keywords: lime column, Embankment on soft consolidating soil, finite element analysis, ground improvement technique.

\section{INTRODUCTION}

Constructing embankments on soft soil with a high level of groundwater results in a rise in stresses leading to strain which causes settlement of stratum. Such settlement is due to a reduction in soil mass volume. When in a fully saturated soil environment, water in voids and soil particles are presumed to be incompressible, volume reduction takes place due to removal of water and this contributes to high lateral pressures and movement. Over settling, slopes and bearing failures, which resulting in delay in construction. In such situations, soil improvement techniques are often used to improve stability and reduce the time of consolidation on a soft soil with high ground water. Stability and consolidation time are two main factors in designing and building the foundation on soft soil. If a lime column is inserted vertically in the ground, it can significantly shorten the drainage path of soft clay reservoirs and significantly increase ground rigidity and strength in a short time. Lime columns are now regarded as the most cost-efficient ground improvement techniques worldwide, where soft compressible clay construction is unavoidable and have been applied in soft soil techniques such as embankment construction on soft soil. This system consists of a lime column which is designed to support embankment filling and reinforce the ground with designed length and diameter. Fig. 1 shows the lime column inserted into the ground which supports the embankment fill for strengthen and stiffen soft soil having high ground water

Revised Manuscript Received on February 15, 2020.

* Correspondence Author

M Prasanna Kumar*, Assistant Professor (Sr. Scale), Civil Engineering Department, Manipal Institute of technology, MAHE, Manipal, India. Email: prasannakumar18186@gmail.com

(C) The Authors. Published by Blue Eyes Intelligence Engineering and Sciences Publication (BEIESP). This is an open access article under the CC BY-NC-ND license (http://creativecommons.org/licenses/by-nc-nd/4.0/) level. In recent years, there has been considerable development in understanding the behavior of embankment resting soft consolidating soil with a high groundwater level. Zheng et al. studied CFG-lime composite field pile construction theory and implementation [1]. The two-dimensional geo-synthetic reinforced embankment on deep mixed column has been analysed by Han et al [2]. Huang Analyzed deep mixing columns under two and three dimensional embankments [3]. Geotextile reinforced embankment analyzed using computational and analytical tools over deep mixed columns by Madhyannapu [4]. 3-dimensional finite element analysis conducted on the CFG column of composite structures of different lengths and diameters by Zheng et al [5]. Simulations of Finite elements to model the multi-column support road embankment done by Abusharar et al [6]. Kumar et al made analytical study on Coir fiber drain's performance for enhancing soft ground in the construction of embankments [9]. Some of the experimental studies are carried out with randomly distributed coir fibers improved the strength of the soil by sarvade et al [8]. In the present work the effectiveness to use lime columns for the embankments on soft soil is studied

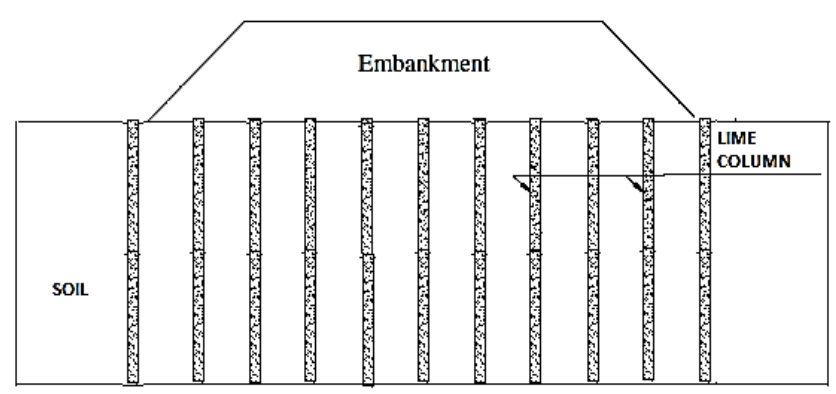

Fig. 1.Embankment supported by lime column

\section{MODELING OF SOIL WITH LIME COLUMN}

The model of an embankment sup-ported on lime column considered for the analysis as shown in Fig.2. As shown in the figure, the embankment has crest width of $11 \mathrm{~m}$, height of $2 \mathrm{~m}$ with side slope 1:1. It is supported on a lime columns of length of $5 \mathrm{~m}$ and diameter $0.5 \mathrm{~m}$. The lime columns are modelled using a two noded plane frame element with three DOF (two transnational and one rotational) whereas, the soil is modelled using a four noded plane strain quadrilateral element. Only the half of the embankment and the soil for study is taken into account because of symmetry. 


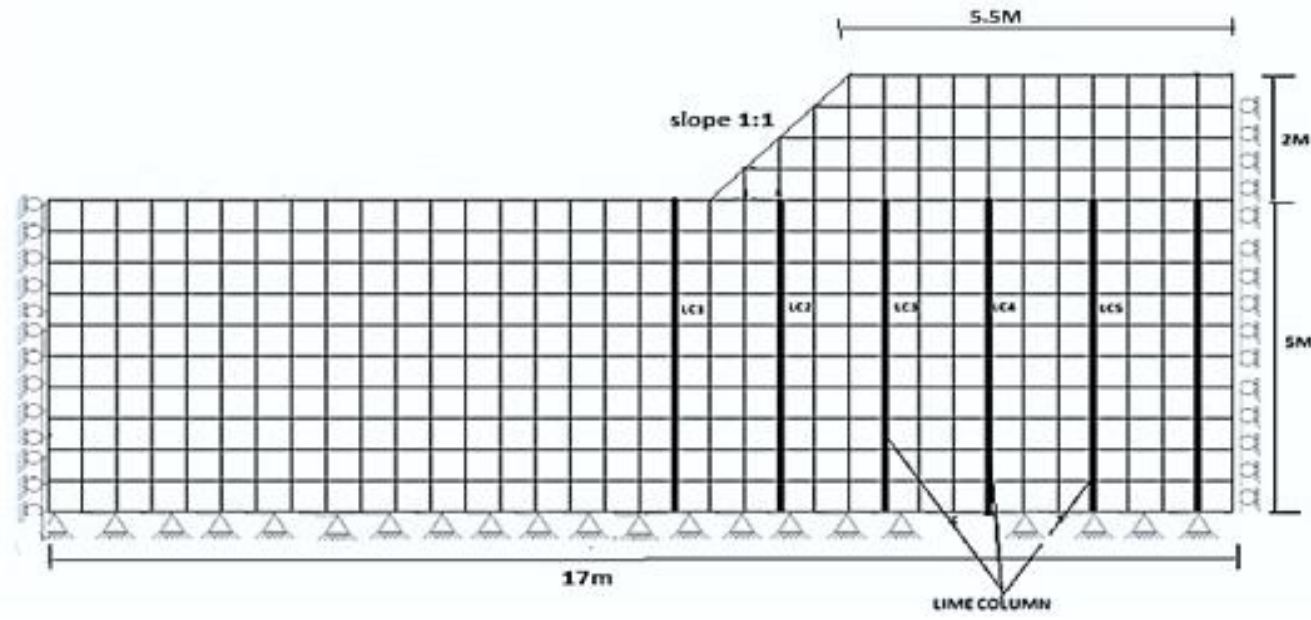

Fig. 2.Finite element model of an embankment supported on lime column

Horizontal displacement at the sides is restricted, while the horizontal and vertical displacement at the bottom of the soil are restricted. It is assumed that the embankment is constructed in stages. The soil stress- strain behavior is presumed to be non-lining and modeled by a Cam-Clay model. The properties of soft soil, embankment and lime column are shown in table 1 and 2, the settlement profile of the ground below the embankment and the axial forces on the lime column are obtained at various time intervals from end of construction till the end of consolidation.

Table 1 Material property of embankment and soft soil

\begin{tabular}{|l|l|}
\hline \multicolumn{2}{|c|}{ MATERIAL PROPERTIES } \\
\hline Elastic modulus, $\mathrm{E}, \mathrm{kN} / \mathrm{m}^{2}$ & 5000 \\
\hline Poisson's ratio, $\mu$ & 0.25 \\
\hline Unit weight, $Y, \mathrm{kN} / \mathrm{m}^{3}$ & 17 \\
\hline Effective cohesion, $\mathrm{c}^{\prime}, \mathrm{kN} / \mathrm{m}^{2}$ & 0 \\
\hline Angle of internal friction $\emptyset^{\prime}$ & $30^{\circ}$ \\
\hline
\end{tabular}

Table 2 Material property of lime column

\begin{tabular}{|l|l|}
\hline \multicolumn{2}{|c|}{ MATERIAL PROPERTIES } \\
\hline Elastic modulus, E, $\mathrm{kN} / \mathrm{m}^{2}$ & $2 \times 10^{4}$ \\
\hline Poisson's ratio, $\mu$ & 0.15 \\
\hline
\end{tabular}

\section{RESULTS AND DISCUSSION}

The settlement profile of the ground below the embankment and the axial forces on the lime column are obtained at various time intervals for the embankment on soft soil with and without lime column and are compared in order to study the effectiveness of providing lime column as ground improvement technique. Fig.3 shows the settlement profile of the ground below the embankment at the end of consolidation. The variation of axial forces in lime columns 1 and 5 with depth at the end of construction and at the end of consolidation are shown in Figs. 4 and 5. From these figures, it can be observed that

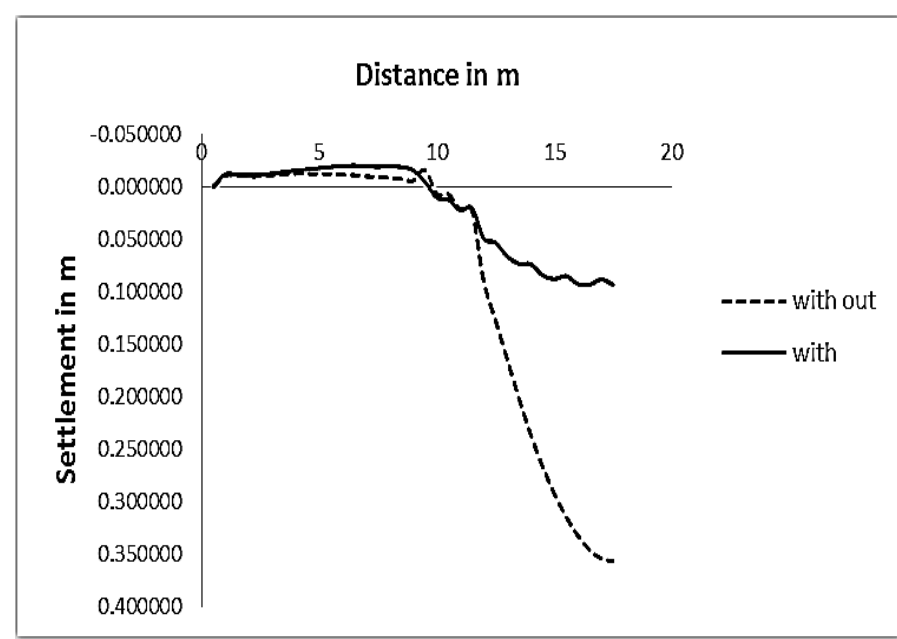

Fig. 3.Settlement profile of the ground below the embankment with and without lime column at the end of consolidation

Axial forces on the lime column 1 and lime column 5 at the end of construction and at the end of consolidation indicates that the forces in both the lime columns are lesser immediately after the construction of embankment compared to the forces in the lime columns at the end of consolidation. This is because, immediately after the construction, the major load of the embankment is transferred to the pore fluid and the load transferred to the soil and columns are less. However, as the time increases, the pressure in pore fluid decreases due to consolidation and the load transfers to the soil mass and lime columns. Thus there is a significant increase in the axial force in the lime columns at the end of consolidation compared to the load at the end of construction. Also, it can be observed that the load on column 1 increases with depth reaches a maximum value at about $3 \mathrm{~m}$ from the ground surface and then decreases as the depth increases both at the end of construction and end of consolidation.

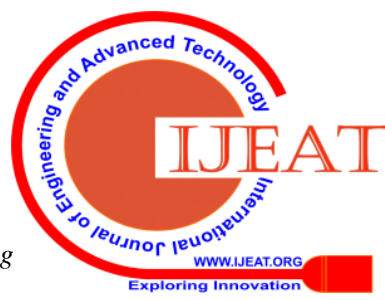


However, for the lime column 5 provided below the center of the embankment the axial load is minimum near the ground surface and increases with the depth.

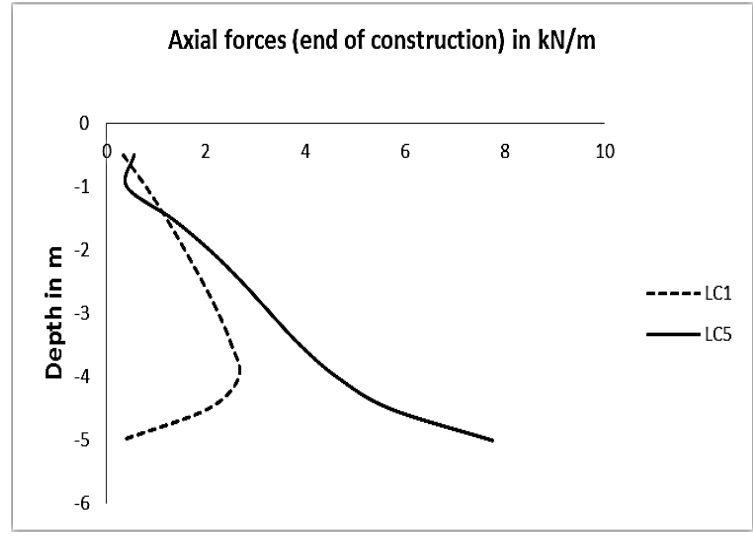

Fig. 4.Axial forces on the lime column at the end of construction.

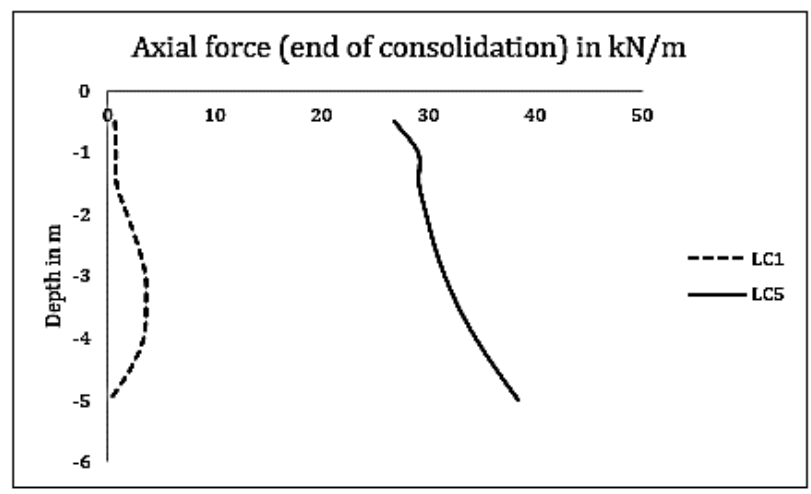

Fig.5. Axial forces on the lime column at the end of consolidation.

\section{SUMMARY AND CONCLUSIONS}

Lime column performance is analyzed using the finite element approach in order to improve soft soil below the embankment.

The study draws the following conclusions

- Addition of lime column in soft consolidating soil reduces the settlement after the construction of embankment.

- The axial force in the lime column is lesser immediately after the construction of embankment because major load of the embankment is transferred to the pore fluid.

- The axial force in the lime columns increases significantly at the end of consolidation compared to the load at the end of construction.

\section{REFERENCES:}

1. Zheng JJ, Abusharar SW, He C (2005), "Design theory and application of CFG-lime piles composite ground", International conference on ground improvement techniques, Coimbra, Portugal; p. 651-6.

2. Han J, Huang J, Porbaha A (2005), "2D numerical modeling of a constructed geosynthetic-reinforced embankment over deep mixed columns", "Contemporary issues in foundation engineering", ASCE; 2005.

3. Huang J, Han J, Porbaha A (2006), "Two and three-dimensional modeling of DM columns under embankments", GeoCongress, ASCE, (187)249:1-5.

4. Madhyannapu RS, Puppala AJ, Hossain S, Han J, Porbaha A. (2006), "Analysis of geotextile reinforced embankment over deep mixed columns using numerical and analytical tools", GeoCongress, ASCE.
5. Zheng JJ, Abusharar SW, Wang XZ (2008), “Three-dimensional nonlinear finite element modeling of composite foundation formed by CFG-lime piles", Comput Geotech, 35(4):637-43.

6. Sari W. Abusharar, Jun-Jie Zheng *, Bao-Guo Chen (2009), "Finite element modeling of the consolidation behavior of multi-column supported road embankment", Computers and Geotechnics, 36:676-685.

7. Sangseom Jeong, Jaeyeon Cho (2012), "Three dimensional analysis of piled raft foundation in clay soils", International Journal of Geo-Engineering; 4(1): 11-22.

8. Purushotham G. Sarvade, Deepak Nayak (2017), "strength characteristics of Randomly distributed coconut coir Reinforced lithomargic clay", IJCIET, Volume 8, Issue 5, pp. 1122-1134

9. M Prasanna Kumar and Agrahara Krishnamoorthy (2018), "Effectiveness of coir fiber drain to improve the soft soil in embankment construction", IJCIET, Volume 9, Issue 6, pp. 1485-1489

\section{AUTHORS PROFILE}

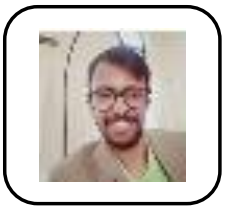

M Prasanna Kumar, Assistant Professor (Sr. Scale), Dept. of Civil Engineering, Completed his MTech in structural engineering, perceiving Phd, and doing his research in the domain of soil structure interaction. Published papers in various Scopus indexed journals, National and international conferences. 